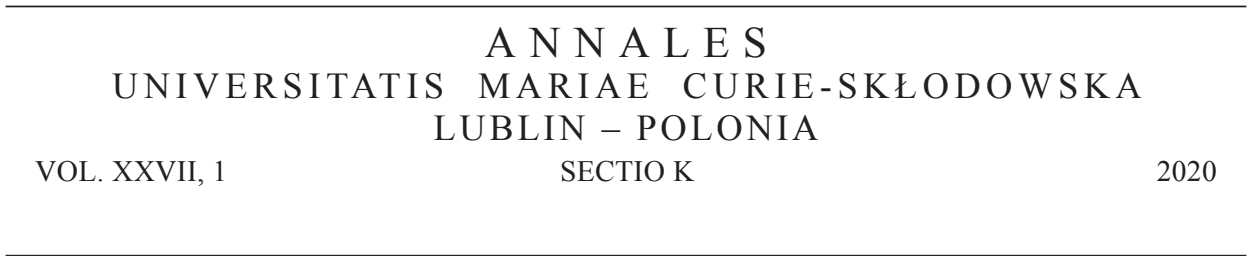

Uniwersytet Śląski

JAROSŁAW TOMASIEWICZ

ORCID ID: 0000-0001-9750-5256

\title{
„Czwarta droga”. Radykalizm chrześcijański w Drugiej Rzeczypospolitej
}

The "Fourth Way". The Christian Radicalism in the Second Republic

\section{ABSTRAKT}

Artykuł omawia ideologię chrześcijańskiego radykalizmu egzystującego w okresie międzywojennym w Polsce. Do jej zbadania wykorzystano analizę tekstów programowych i publicystycznych tego nurtu w ich kontekście społeczno-politycznym. Cechą charakterystyczną polskiego chrześcijańskiego radykalizmu było połączenie obrony ustroju demokratycznego i postulatu reform społecznych na fundamencie katolicyzmu. Autor stara się odpowiedzieć na pytanie o przyczyny słabości chrześcijańskiego radykalizmu w Polsce. Jak się wydaje, wynikała ona z elitarnego charakteru tego nurtu, który był reprezentowany przede wszystkim przez organizacje akademickie i intelektualne periodyki.

Słowa kluczowe: Druga Rzeczpospolita, katolicyzm społeczny

\section{WSTĘP}

W Polsce nie pojawił się znaczący ruch lewicy chrześcijańskiej jak Le Sillon i Ligue de la jeune République we Francji czy Partito Popolare Italiano we Włoszech. Niemniej jednak na mapie ideowej Drugiej Rzeczypospolitej można odnaleźć - słabe wprawdzie i rozproszone - radykalne środowiska chrześcijańskie. Zajmowały one pozycję szczególną, łącząc antykapitalizm i antysocjalizm z internacjonalizmem i demokratyzmem (co odróżniało je od narodowych radykałów). Ponieważ antylibe- 
ralny nacjonalizm „młodych” narodowców Tadeusz Włudyka nazwał „trzecią drogą” [Włudyka 1994], radykalnych chrześcijan możemy zaklasyfikować jako „czwartą drogę", alternatywną wobec liberalizmu, marksizmu i faszyzmu.

Celem niniejszego artykułu jest wykazanie, że pomimo rozpowszechnionego (i w zasadzie słusznego) przekonania o konserwatywnym społecznie charakterze polskiego katolicyzmu również w Polsce można dostrzec nurt postępowo-chrześcijański. Stwierdzenie istnienia tego zjawiska pociąga za sobą kolejne pytania: jaka była struktura ruchu, jego zaplecze społeczne, źródła inspiracji ideowej, pryncypialne idee. I wreszcie - dlaczego jego rozmiary były tak znikome, że samo istnienie budzi wątpliwości? Postaram się zweryfikować hipotezę, że słabość polskiego ruchu postępowo-chrześcijańskiego wynikała z elitarno-intelektualnego charakteru i braku autentycznej więzi z masami.

\section{POCZĄTKI}

W Polsce niepodległej jednym z pierwszych ugrupowań o chadeckim profilu był Narodowy Związek Chrześcijańsko-Społeczny utworzony w 1919 r. w Krakowie. Program NZChS miał charakter jednoznacznie demokratyczny: opowiadał się za republikańską formą rządów, rządami „przedstawicielstwa ludowego”, pięcioprzymiotnikową ordynacją wyborczą, równouprawnieniem kobiet, wolnością słowa i stowarzyszeń, uznaniem praw mniejszości narodowych, wolnością wszystkich wyznań. W sprawach społeczno-gospodarczych Związek postulował reformę rolną, powszechne ubezpieczenia społeczne, 8-godzinny dzień pracy, udział robotników w zyskach i zarządzaniu przedsiębiorstwami, nacjonalizację bogactw naturalnych (lasy, kopalnie), środków komunikacji i strategicznych gałęzi przemysłu oraz - docelowo - uspółdzielczenie wytwórczości [Program Narodowego Zwiazku Chrześcijańsko-Spotecznego 1919: 5, 7-8, 14-16]. Program utworzonego w 1920 r. ogólnopolskiego Chrześcijańsko-Narodowego Stronnictwa Pracy był dużo bardziej umiarkowany: alternatywę dla kapitalizmu widziano jedynie w stopniowym rozwoju akcjonariatu pracowniczego, nie wspominając o nacjonalizacji [Zarys programu Chrześcijańsko-Narodowego Stronnictwa Pracy (Chrześcijańskiej Demokracji) 1922: 11].

W podobnym co NZChS kierunku szło Chłopskie Stronnictwo Radykalne. Jego założyciel ks. Eugeniusz Okoń przed I wojną światową był współpracownikiem ks. Stanisława Stojałowskiego, po zakończeniu wojny stanął na czele tzw. Republiki Tarnobrzeskiej. Na wiecu pod pomnikiem Bartosza Głowackiego wołał wówczas: „Żołnierze, robotnicy i ty biedoto chłopska! [...] Bóg tak sprawił, że poniżani będą wywyższeni. [...] Precz z tymi pasożytami, co nie orzą, nie sieją, a z chłopskiej jedynie skóry buty szyją dla siebie. [...] Właśnie dzwonią [w kościele], ale już nie na »anioł pański«, ale na twój »anioł chłopski«, więc oddajmy się w opiekę Matki Boskiej Dzikowskiej i zanućmy »Serdeczna Matko«" [Spiss 1936: 175-176]. 
Założone przez niego w 1919 r. Stronnictwo łączyło program radykalnych reform społecznych z postulatem demokratyzacji Kościoła. W programie uchwalonym w 1922 r. deklarowało, że „stać będzie mocno przy wierze ojców i religię jako rzecz nadziemską szanować" [Program Chtopskiego Stronnictwa Radykalnego 1922: 7], jednak, jak mówił Okoń, „chcemy z tej religii wyrzucić te śmiecie, [...] które służą jaśnie wielmożnym, kapitałowi i bogaczom”. Zgłosił więc projekt ustawy, by „W miejsce obecnych patronów wprowadzono [...] parafialne komitety kościelne, wybrane przez ogół wiernych z powszechnych wyborów, które by w porozumieniu z władzą kościelną wykonywały obsadzanie probostw". Co więcej zapowiadał, że „my będziemy nawet żądali prawa mianowania biskupów”. W ten sposób, obiecywał, „lud nasz wyzwoli się nie tylko z pęt obszarniczych, [...] ale wyzwoli się z tej niewoli duchowej, którą narzucili mu nasi biskupi autokraci i nasi niedobrzy proboszczowie" [Rek 1962: 233-234]. ChSR rozpadło się jednak po kilku latach.

Na placu boju pozostały tylko efemeryczne grupy rozłamowe z Polskiego Stronnictwa Chrześcijańskiej Demokracji, takie jak Chrześcijańska Demokracja Robotnicza w Łodzi czy Chrześcijańska Demokracja - Lewica w Płocku [Krzywobłocka 1974: 337, 405]. Polski radykalizm katolicki był pozbawiony partyjnej reprezentacji. Nie udało mu się też pozyskać naturalnego, zdawałoby się, zaplecza w Chrześcijańskich Związkach Zawodowych, które pozostawały najbardziej oportunistycznym segmentem ruchu związkowego. Do rzadkich przejawów robotniczego radykalizmu chrześcijańskiego należała publicystyka krakowskiego pisma „Zbawca Ludu” [Tomasiewicz 2018: 451-462].

Chrześcijański radykalizm egzystował na marginesie głównego nurtu chadecji, rozwijany przez nieliczne grupy intelektualistów zafascynowanych wyrafinowanymi koncepcjami o zagranicznej na ogół proweniencji - najpierw ekumenizmem YMCA, potem francuskim personalizmem. Dopiero w latach 30 . XX wieku przyjął wyrazistą formułę, stanowiąc w pewnym sensie refleks francuskich prądów młodokatolickich („Esprit”, „Ordre Nouveau”, „La Revue du Siecle”), które stawiały sobie za zadanie ,walkę z komunizmem, kapitalizmem i faszyzmem” [Wyka 1935; Lewis 1970; Hellman 2002: passim].

W Polsce za wczesnego prekursora tego nurtu można uznać Chrześcijański Związek Akademicki - międzywyznaniową organizację powstałą na początku 1921 r. z inspiracji Chrześcijańskiego Stowarzyszenia Młodych Mężczyzn (YMCA). Od początku podkreślała wszakże swój narodowopolski charakter: „Dążymy do zachowania najściślejszej łączności duchowej z całą dotychczasową polską tradycją odrodzeńczą, a potwierdzenia i pogłębienia narodowego charakteru ideologii naszej w studium polskiej myśli moralnej, zawartej w życiu i dziełach naszych wieszczów i myślicieli". Początkowo w działalność ChZA zaangażowana była też grupa narodowców z Tadeuszem Bieleckim (późniejszym prezesem Stronnictwa Narodowego) na czele, jednak w 1923 r. odeszła do Młodzieży Wszechpolskiej. Związek odrzucał bowiem nacjonalizm - jego deklaracja stwierdzała: „Występujemy stanowczo przeciw doktrynie egoizmu narodowego jako normy etycznej dla jednostek i społeczeństw, potępiając 
taką doktrynę jako zasadniczo niemoralną". Istotą ideologii ChZA była koncepcja przeprowadzenia zmian społecznych przez odrodzenie moralne - głoszono, że „gdy uciśnieni wytworzą siłę nie tylko fizyczną, ale i moralną możliwe jest zwycięstwo prawdy i prawdziwa przebudowa społeczna". Chrześcijański Związek Akademicki kultywował ideały demokratyczne, co skłaniało jego członków do sympatyzowania z piłsudczykami. Autorytarna ewolucja sanacji (zwłaszcza po procesie brzeskim 1930 r.) doprowadziła do kryzysu Związku, który na początku lat 30. XX wieku uległ rozkładowi [Gajewski 1987: 138, 212, 220, 224].

\section{„VERBUM"}

Na orbicie ChZA znalazło się również początkowo „Kółko” ks. Władysława Korniłowicza, choć po 1922 r. poszło już własną drogą. Ta nieformalna grupa młodej inteligencji uformowała się w 1917 r. Trzon grupy stanowili: Zofia Landy (później siostra Teresa), Zofia Sokołowska (siostra Katarzyna), jej siostry - Henryka i Barbara, Franciszek Tencer, Rafał M. Blüth, Tadeusz Baykowski i Stanisław Krzywoszewski; związani z nią byli także m.in. Zofia Nałkowska, Czesław Miłosz, Karol Irzykowski, Jerzy Liebert i inni. Cechą charakterystyczną tego środowiska był fakt, że większość jego uczestników rekrutowała się z osób religijnie indyferentnych lub konwertytów (zresztą także sam Korniłowicz wywodził się z rodziny o poglądach pozytywistycznych i racjonalistycznych). To sprawiało, że „kółkowiczom” nie wystarczał tradycyjny katolicyzm - powierzchowny i obrzędowy - ale chcieli chrześcijaństwa świadomego, umocnionego rozumowo. Jak pisała jedna ze współzałożycielek „Kółka”, s. Teresa: „Religia przyjęta w entuzjazmie wiary domagała się pogłębienia i ugruntowania intelektualnego w myśl zasady fides quaerens intellectum”. Zarazem jednak „kółkowicze” nie ograniczali się do modlitw i dyskusji w Bibliotece Wiedzy Religijnej, ale dawali również praktyczny dowód miłości bliźniego, angażując się w działalność Zakładu dla Ociemniałych w Laskach (dwie z założycielek „Kółka” wstąpiły nawet do zakonu Sióstr Franciszkanek Służebnic Krzyża, prowadzącego ów Zakład). Współpraca między „Kółkiem" a środowiskiem Lasek, trwająca od 1918 r., uległa zacieśnieniu, gdy w $1930 \mathrm{r}$. ks. Korniłowicz został kapelanem Sióstr [Gajewski 1987: 231-218; Łętocha 2008].

Na początku lat 30. XX wieku w środowisku „Kółka” i Lasek, coraz dojrzalszym intelektualnie i coraz mocniej odczuwającym swą ideową odmienność, pojawiła się myśl wydawania własnego periodyku. W 1934 r. ukazał się pierwszy numer kwartalnika „Verbum”, którego redaktorem naczelnym został Konrad Górski, a później ks. Korniłowicz. Redakcję tworzyli: T. Baykowski, R.M. Blüth, T. Landy, Helena Morawska, Zygmunt Serafinowicz i Maria Winowska [Chrzanowski 1999].

Celem „Verbum” było nie tylko wzmocnienie intelektualnych zrębów polskiego katolicyzmu, ale też wypracowanie jego nowej formuły. Miał to być katolicyzm czynny, twórczy, otwarty, nowoczesny, dynamiczny, optymistyczny. Domagano się „uznania pozytywnej wartości świata”, odrzucając „manichejskie” podejście do 
doczesności. „Historja nie jest [...] źródłem pesymizmu”, pisał na łamach „Verbum” Regis Jolivet [Jolivet 1935]. Postulowano więc włączanie się w procesy społeczne, s. Teresa głosiła wręcz konieczność scalenia mistycyzmu z ,poczuciem społecznym”: „sprawdzianem mistyki jest [...] zwykłe codzienne życie wierzącego" [Teresa 1935]. „Tradycjonalizm” i „ciasny rygoryzm” konserwatywnych katolików krytykowano jako ,postawę tchórzliwą, [...] wsteczną”. Podkreślano natomiast zbieżność katolicyzmu i humanizmu rozumianego jako „dążenie do [...] wszechstronnego kultywowania różnych umiejętności”, co pociągało za sobą imperatyw twórczości [Siwecki 1936]. Z tego powodu Jan Sałamucha wytykał katolickiej inteligencji pasywność, uważając, że przyzwyczajona jest do roli „,widowni” [Sałamucha 1936]. „Verbum” interesowało się zdobyczami nauki (uznanej za „środek służenia Bogu”), starając się wpleść je w naukę Kościoła [Siwecki 1936; Maritain 1934]. Przy całej swej elastyczności grupa zaznaczała granice możliwych ustępstw: „,katolik nie może zminimalizować swojego programu metafizycznego czy dogmatycznego" [Teresa 1938].

Otwartość na nowe idee prowadziła w warunkach kryzysu gospodarczego do antykapitalistycznego nastawienia „Verbum”. Postawę środowiska wyrażały ironiczne słowa Leopolda Caro: „My [...], nie dotknięci łaską wiary w kapitalizm”. Katoliccy intelektualiści kwestionowali dogmaty liberalizmu ekonomicznego zarzucając mu fatalistyczną uległość wobec zła społecznego, krytykując koncepcję homo oeconomicus, twierdząc, że w życiu gospodarczym wola ludzka ma większe znaczenie od rzekomo obiektywnych praw (,w dziedzinie gospodarczej nie ma praw niezmiennych") [Caro 1935]. Potępiali panujące w kapitalizmie ,nieludzkie [...] stosunki społeczne", proponując jako alternatywę respektowanie zasad chrześcijańskich w życiu codziennym [Siwecki 1938].

Chrystianizacja życia gospodarczego miała polegać na przezwyciężeniu alienacji pracy przez jej uduchowienie: „,współdziałać w dziele odkupienia przez [...] każde uderzenie młotem i każdy obrót obrabiarek" [Siwecki 1938]. Egalitaryzm wynikający z „bezwzględnej wartości każdej duszy ludzkiej” członkowie grupy przenosili na stosunki społeczne, by głosić „,wyrównanie poziomów życia przez likwidację zarówno nędzy jak zbytku”. Ich zdaniem „twórczość gospodarcza jest służbą społeczną, której celem jest zaspokojenie potrzeb bliźnich i stwarzanie egzystencji możliwie najlepszej dla największej ilości ludzi”. Wynikał stąd skierowany przeciw bezmyślnemu konsumpcjonizmowi postulat „,produkcji celowej”. Konkretny program gospodarczy pozostawał jednak ostrożny. „Verbum” oponowało zarówno wobec indywidualizmu, jak i kolektywizmu, uważając, że obie koncepcje wyrastają z ,naturalnego egoizmu i walki o byt” [Niesiołowski 1938]. Trzecia droga miała się opierać na zasadach upowszechnienia własności („,nie ma [...] ani wolności ani równości bez minimum bodaj własności prywatnej”) i samorządowej organizacji produkcji (korporacjonizm demokratyczny) [Caro 1935]. „Wprowadzić Chrystusa do fabryk mogą tylko robotnicy", dodawał Jerzy Siwecki [1938].

Krytyka kapitalizmu z pozycji tercerystycznych była wówczas częsta na skrajnej prawicy, od tejże odróżniał jednak „Verbum” pozytywny stosunek do demokracji. 
Jak wykładał Andrzej Niesiołowski w artykule Personalizm i jego perspektywy: „Ideą centralną jest [...] koncepcja uspołecznienia człowieka przy jednoczesnym zachowaniu jego indywidualności i wolności" [Niesiołowski 1938]. Personalistyczna perspektywa pisma nakazywała zachować równowagę między tymi wartościami. Jak przyznawano w 1937 r.: „Człowiek wierzący, który w epoce liberalizmu poczuwał się do obrony zasady [...] autorytetu teraz zwraca się ku drugiemu zagrożonemu dobru - wolności”. Idea wolności rozumiana była odmiennie niż w liberalizmie. Krytykowano koncepcję „wolności jako pojęcia negatywnego, wolności jako braku wszelkiej granicy”. Konstatując, że „wolność jest faktem wewnętrznego doświadczenia i odczuwamy ją jako dobro", rozróżniano dwie wolności: wolność natury zmysłowej i wolność natury duchowej. Między nimi miał panować konflikt: „Jedną wolność okupuje się drugą wolnością". Ponieważ wolność natury zmysłowej miała sprowadzać „niewolę swych rozpętanych instynktów lub wyhodowanej [...] pychy”, uznawano, że „prawdziwa wolność zaczyna się tam, gdzie się zjawia się pierwiastek duchowy z charakteryzującą go świadomością" - a więc wola potrafiąca okiełznać popędy. By jednak znieść bolesny rozziew między wolnością zmysłową i duchową, niezbędny jest „stan łaski” - czynnik nadprzyrodzony, który daje „swobodę miłości” [Dwie wolności 1937]. W ten sposób Marksowska „uświadomiona konieczność" zostaje przeistoczona w Augustiańskie Dilige et quod vis fac.

Mimo odmiennych założeń teoretycznych „Verbum” we wskazaniach praktycznych bliskie było liberalizmowi. Uznając, że „każdy, nawet błędny, kierunek myślowy [...] ma w sobie cząstkę prawdy” [Dwie wolności 1937], krytykowało „,nietolerancję wobec inaczej myślących” [Niesiołowski 1938]. Za cel stawiało sobie „obronę osoby ludzkiej z jej prawem do posiadania przekonań [...] przed [...] antyosobową wszechobecnością państwa" [Siwecki 1934]. Z tych pozycji zwalczało totalitaryzm, któremu wytykało „kult grupy jako wartości absolutnej, [...] lekceważenie lub zupełne odrzucenie praw jednostki, etykę kolektywistyczną, centralistyczną planowość, [...] militaryzację społeczeństwa i ustrój totalny, oparty na rządach monopartii, [...] niewolę sumien”. I puentowało: „Walka z religią, broniącą zawsze praw sumienia ludzkiego, jest konsekwencją nieuniknioną takiego systemu" [Niesiołowski 1938]. Nazizmowi dodatkowo zarzucano antysemityzm i rasizm zaprzeczający chrześcijańskiemu uniwersalizmowi. Opublikowano List Episkopatu Niemieckiego, który stwierdzając, że naziści „źródła Chrystusowej łaski pragną zastąpić rzekomą »tajemnicą krwi nordyckiej «”, oceniał: „Jest to bunt przeciw Chrystusowi [...], kiedy nowocześni poganie żądają [...] narodowego, niemieckiego kościoła, o odrębnej [...] nauce i moralności" [List Episkopatu Niemieckiego 1934].

Krytyka totalitaryzmów miała charakter symetryczny - R.M. Blüth sytuował „Verbum” $\mathrm{w}$, ,światowym obronnym ruchu antybolszewickim, który [...] jednocześnie wymierzony jest przeciw antychrześcijańskim tendencjom hitlerowskim" [Blüth 1936]. Ale, powtórzmy, postulowana „rewolucja moralna” była zwrócona nie tylko przeciwko komunizmowi i nacjonalizmowi, ale również przeciw umysłowości „małomieszczańskiej” (która „wyróżnia się [...] brakiem bezinteresowności”, 
drobnomieszczanin „w praktyce jest ateuszem”) i kapitalistycznej („tak surowo potępionej w encyklice »Quadragesimo Anno «"). Franciszek M. Braun wszystkim tym ideologiom zarzucał „wspólne pochodzenie naturalistyczne”, zastępowanie kultu Boga ersatzami i „sprzeczność radykalną z Ewangelią”, kontrastując „troski doczesne mentalności burżuazyjnej i prymat nieśmiertelnej duszy”, „nieograniczone pożądanie bogactw [...] i duch ubóstwa”, ,poszanowanie osobowości ludzkiej [...] i pochłonięcie jej bez reszty przez pewną grupę socjalną”, ,partykularyzm narodowy [...] i miłość powszechną" [Braun 1937].

\section{„ODRODZENIE”}

W tym samym kierunku ewoluowało Stowarzyszenie Katolickiej Młodzieży Akademickiej „Odrodzenie”, założone w 1919 r. Początkowo nic nie wskazywało na późniejszą ewolucję organizacji w kierunku postępowego katolicyzmu. „Odrodzenie” powstało na orbicie obozu konserwatywnego, akceptowało katolicki nacjonalizm, zawarło antylewicowy sojusz z Młodzieżą Wszechpolską. W 1923 r. rozpoczął się jednak konflikt $\mathrm{z}$ endekami spowodowany tyleż ich monopolistycznymi dążeniami (jak powiedział przywódca MW Jan Mosdorf, „,nie uznajemy nikogo poza nami”), co koncepcją ponadwyznaniowej jedności narodu. Katolicyzacja polskiego nacjonalizmu, jaka dokonała się na początku lat 30. XX wieku, powinna zniwelować różnice między endekami a odrodzeniowcami, jednak SKMA, ciążące coraz bardziej ku katolickiemu integryzmowi, uważało ożywienie religijne młodzieży narodowej za powierzchowne. O ile w deklaracji z 1923 r. członkowie „Odrodzenia” wskazywali: „Jesteśmy nacjonalistami”, to sześć lat później dystansowali się już od szowinizmu narodowego jako owocu „nieuporządkowanej miłości rodaków”. Opór budziła też radykalizacja antysemityzmu endeków: choć SKMA początkowo popierało numerus clausus, to jednak w latach 30. $\mathrm{XX}$ wieku potępiało ekscesy antyżydowskie (jak zauważył obserwator, jedynie na zdominowanym przez odrodzeniowców Katolickim Uniwersytecie Lubelskim mógł się odbyć mecz piłki nożnej miejscowej reprezentacji akademickiej z drużyną żydowską). Z kolei zaangażowanie w problematykę społeczną pchało członków SKMA ku zainteresowaniu się koncepcjami lewicowymi - w spotkaniach dyskusyjnych „Odrodzenia” nieraz brali udział marksiści. Również w bratniej „Iuventus Christiana” pojawili się sympatycy socjalizmu: ks. Piotrowicz, B. Tekliński [Turowski 1987: 57, 400, 406; Gajewski 1987: 129-130, 151-152, 179, 182-183, 185, 255, 296].

Deklaracja „Odrodzenia” zrywała z rozpowszechnionym w środowiskach katolickich kwietyzmem, głosiła aktywizm, społeczne zaangażowanie, reformę moralną i strukturalną. Czytamy w niej: „Zrywamy z fałszywą pokorą i ckliwie pojętą miłością chrześcijańską, wypleniamy lęk i bezradność wobec idących olbrzymich, a nieraz bolesnych przewrotów współczesnych. Katolik-Polak musi iść na przedzie i władać życiem, bo z ducha Chrystusowego płynie wiara w życie oraz siły i zapał do jego budowy. [...] Zrywamy stanowczo z zasadą odradzania społeczeństwa bez 
odradzania siebie. [...] odrzucamy typ pracy, który polega na rzeźbieniu własnej duszy w oderwaniu od świata [...]. Chcemy wychować pokolenie ludzi czynu i tworzyć życie polskie we wszystkich jego dziedzinach" [Turowski 1987: 398-399]. SKMA postulowało umocnienie rodziny, ukształtowanie nowej elity w oparciu o inteligencję, organizację życia opartą na kulturze pracy, przezwyciężenie kapitalistycznego wyzysku w duchu demokratycznego korporacjonizmu.

Poglądy radykałów z SKMA wyrażał Eugeniusz Myczka - przewodniczący sekcji zagadnień społecznych warszawskiego „Odrodzenia”. W swej broszurze $O$ polska ideę czynu domagał się uznania prymatu katolicyzmu w życiu społecznym Polski, gdyż, jak uzasadniał, „,dzieje narodu polskiego są [...] najściślej związane z dziejami katolicyzmu w Polsce”. Podkreślał jednak zarazem, że „formy realizacji niezmiennych zasad ulegają [...] zmianom w różnych okresach historycznych", dlatego należy „budować nowy [podkr. J.T.] typ społeczeństwa na odwiecznych, starych zasadach”. Naukę Kościoła Myczka reinterpretował, akcentując, iż „katolicyzm jest ideą na wskroś żywą, bojową i zdobywczą". Z tego punktu widzenia krytykował statyczność katolików nierozumiejących dynamizmu przemian społecznych, a nawet domagał się rozgraniczenia między katolicyzmem ,społecznie-twórczym” i konserwatywnym [Myczka bdw: 20-21, 47, 57-58, 62, 78].

Odrodzony katolicyzm miał być inspiracją reform społecznych. Choć Myczka zaznaczał, że Kościół nie może się wiązać z żadnym ustrojem, to twierdził, że katolicki ustrój społeczny musi być oparty na zasadach sprawiedliwości i miłości społecznej. Uznając, iż „wyzysk hamuje [...] rozwój życia gospodarczego”, postulował „sprawiedliwy podział dochodu społecznego" i ,zwiększanie sił produkcyjnych narodu”. Celem miał być bezklasowy naród, osiągnięty wszakże środkami ewolucyjnymi, na drodze solidaryzmu społecznego - poprzez „oparcie stosunków społecznych na zasadzie współpracy i zjednoczenia wszystkich warstw społecznych”. Jak pisał: „Zmiana ustroju społecznego przez odrodzenie w nas samych idei człowieczeństwa drugich ludzi, jako jedynej miary ich wartości to jednocześnie najpewniejsza droga do urzeczywistnienia sprawiedliwości społecznej, co jest koniecznym warunkiem wewnętrznego [...] zjednoczenia narodu" [Myczka bdw: 67, 72-74, 85].

W sferze politycznej Myczka, krytykując „systemy, oparte na przemocy społeczeństwa nad jednostką", szukał trzeciej drogi między demoliberalizmem i totalizmem - ustroju, który pogodzi „ideę dobra narodu z ideą wolności człowieka”. Na pozór koncepcje Myczki były bliskie programowi „młodych” narodowców. On jednak uważał, że nacjonalizm na równi z komunizmem dąży do „wykluczenia Kościoła od udziału we wpływie na przyszłą rzeczywistość". Nacjonalizm krytykował odsuwanie Boga w sferę metafizyki (hasło „przez naród do Boga!”), twierdząc, że konieczny jest też chrześcijański stosunek do ludzi i innych narodów. Choć dostrzegał odchodzenie „młodych” od nacjonalizmu „pogańskiego”, twierdził, że „objawy te są [...] odosobnione" i uważał, że „nie ma dotychczas nacjonalizmu, jako organicznego wypływu nauki Kościoła" [Myczka bdw: 18, 24-28, 77]. 


\section{ŚRODOWISKO WILEŃSKIE}

Jednym z najsilniejszych i najbardziej zróżnicowanych ideowo ośrodków chrześcijańskiego radykalizmu było Wilno. Bogactwo kultury intelektualnej tego miasta w zderzeniu z nędzą zacofanej peryferii skłaniało do niekonwencjonalnych poszukiwań ideologicznych. Jak wspominał Stanisław Stomma, „,nosiliśmy w sobie bolesny kompleks wewnętrzny [...] - kompleks upokorzenia z powodu stanu kwestii społecznej”. Istotną rolę odgrywała też mozaika narodowościowa regionu, uwrażliwiająca na kulturową różnorodność. „Hasło »polskość to katolicyzm« jest niebezpieczne, stwarza sugestię, że niekatolik nie jest pełnym Polakiem, co jest absurdem i obraża wielu współrodaków”, napisał w 1937 r. wileński „Pax” [Kakareko 2000: 127-149].

W 1928 r. na wileńskim Uniwersytecie Stefana Batorego ukształtowała się nieformalna Grupa Dobrej Woli, której członków (Antoniego Gołubiewa, Stanisława Stomma, Józefa Święcickiego, Czesława Bobolewskiego, Wojciecha Dąbrowskiego, Stanisława Perzanowskiego, Czesława Zgorzelskiego, Henryka Dembińskiego) łączyła fascynacja personalizmem Maritaina i dystrybucjonizmem Chestertona. Grupa włączyła się w działania SKMA i Akcji Katolickiej, nawiązała współpracę z popularnymi duszpasterzami akademickimi: ks. Walerianem Meysztowiczem (kapelanem „Odrodzenia”), o. Kazimierzem Dąbrowskim SJ (moderatorem Sodalicji Mariańskiej Akademików) oraz ks. Henrykiem Hlebowiczem (moderatorem Sodalicji Mariańskiej Akademiczek, doradcą „Iuventus Christiana”, kuratorem Akademickiego Czynu Społecznego). Pod względem politycznym grupę charakteryzowały sympatie piłsudczykowskie, współbrzmiące z prosanacyjnym stanowiskiem wileńskich konserwatystów (,żubrów”). Pozwoliło to na stworzenie antyendeckiego bloku „Odrodzenia” z lewicą i piłsudczykowskim Związkiem Polskiej Młodzieży Demokratycznej, który w 1929 i 1931 r. wygrał wybory do studenckiego Bratniaka. Protekcja „żubrów” pozwoliła też na wydawanie własnego organu - „Żagarów” jako dodatku do konserwatywnego dziennika „Słowo”. Jesienią 1931 r. „Odrodzenie” wraz z pokrewnymi grupami utworzyło Porozumienie Akademickich Katolickich Stowarzyszeń, mające stanowić płaszczyznę działania ruchu katolicko-społecznego [Gajewski 1987: 263-266, 270].

Niebawem jednak w środowisku doszło do kryzysu. Na początku 1932 r. charyzmatyczny lider odrodzeniowców Dembiński opublikował artykuł Podnosimy kurtynę, w którym przewidywał możliwość wywłaszczenia i oparcie gospodarki na centralnym planowaniu. Próbował pogodzić te postulaty z katolicką nauką społeczną, pisząc, że „katolickie prawo własności jest przede wszystkim obowiązkiem socjalnym, jest tytułem do kierownictwa produkcją i tytułem do odpowiedzialności za gospodarzenie, zgodnie z interesami całego społeczeństwa". Odżegnywał się też od komunizmu: „Bardzo nam zależy, by nowy ustrój, który zakwitnie na mogile kapitalizmu, nie zmienił się w system niewolnictwa państwowego ze swoją burżuazyjną biurokracją i kliką partyjną, by nie związał się w jedno z systemem materializmu filozoficznego, z zaborem metafizyki i wiary człowieka w wartości nadziemskie". 
Niemniej jednak wystąpienie Dembińskiego wywołało skandal, doprowadziło do zerwania ze środowiskiem „Słowa”, skonfliktowało „Odrodzenie” z wileńską kurią arcybiskupią (która przyczyniła się do porażki Dembińskiego w wyborach do Bratniaka w marcu 1932 r.). Do ostatecznego rozłamu doszło podczas organizowanego przez SKMA XI Tygodnia Społecznego w Lublinie w sierpniu 1932 r. „Henrycjanie” (oprócz Dembińskiego m.in. Henryk Chmielewski, Maria Żeromska i Władysław Borysowicz z Wilna, Krzysztof Zamojski i M. Bogucka ze Lwowa, Jan Frankowski z Poznania) postulowali wówczas „,hrzest bolszewizmu”: „komunizm należy ochrzcić, gdyż przyszłość zapowiada wiele zmian idących w kierunku komunizmu, a katolicyzm te zmiany uszlachetniłby". Gdy niekwestionowany autorytet młodzieży odrodzeniowej ks. Antoni Szymański wystąpił przeciw koncepcji syntezy chrześcijańsko-marksistowskiej, większość zwolenników Dembińskiego odeszła z SKMA. Określani ironicznie mianem „Koła Matki Boskiej Kazetempowskiej” połączyli się z dysydentami z sanacyjnego Legionu Młodych w Związek Lewicy Akademickiej „Front”, działający nielegalnie na orbicie Komunistycznej Partii Polski [Walka z radykalizmem młodych 1934; Gajewski 1987: 252, 267-269, 283]¹.

Osłabiony PAKS skoncentrował się na stworzeniu własnego organu prasowego. W styczniu 1933 r. ukazał się pierwszy numer pisma (w założeniu miesięcznika) „Pax”. Redakcję tworzyli: A. Gołubiew, S. Stomma, J. Święcicki, J. Frankowski, Leokadia Małunowiczówna, Witold Rudziński, Gustaw Nowodworski, Marian Pruba, Zbigniew Cieślik, Irena Sławińska, Jerzy Turowicz, Wacław Tarasiewicz, Iwo Jaworski, Jan Rutski, ks. dr Piotr Śledziewski. Po roku opublikowano dwa dokumenty programowe grupy. We Wstępie do Manifestu redakcja jako punkt wyjścia postulowała „zdanie sobie sprawy z nicości kultur dzisiejszych. Nie komunistycznej tylko, nie burżuazyjnej tylko - lecz obu". Wnioski z tego płynące prowadziły jednak nie do nihilizmu, ale aktywizmu: „By się zrodziła tęsknota do czegoś nowego, trzeba stworzyć poczucie pustki. Trzeba tę pustkę dnia dzisiejszego wykazać, by powstało pragnienie, chęć, wola tworzenia Nowego Jutra. Trzeba szukać! Iść na poszczególne placówki - religijne, naukowe, artystyczne, społeczne, zawodowe - i tam szukać nowych form, nowego wyrazu. Sprawdzać nasze osiągnięcia kryterium Ewangelii i życia. Nie wlec się z tyłu! Przodować!”. W Manifeście środowisko PAKS konstatowało: „Żyjemy na schyłku kultury kapitalistycznej, pod grozą przyjścia komunizmu”.

\footnotetext{
1 Szerzej o H. Dembińskim zob. [Tomasiewicz 2007]. Był to przykład najskrajniejszy, jednak na platformie antyfaszyzmu dochodziło do przypadków mniej lub bardziej sporadycznej współpracy chrześcijańskich demokratów z lewicą. W Kaliszu w 1934 r. PPS utworzyła spółdzielnię z ks. prałatem Janowskim na czele; ks. prałat Nowakowski z warszawskiego kościoła Zbawiciela w 1935 r. zorganizował międzypartyjne spotkanie młodzieży z udziałem socjalistów i komunistów na temat zagrożenia ze strony hitlerowskich Niemiec; w 1936 ks. Szydelski (Dom Katolicki we Lwowie) znalazł się w prezydium jednolitofrontowej akademii pod hasłem ,przeciw sanacji, przeciw faszyzmowi, przeciw uciskowi”. Ze strony PPS m.in. Ludwik Winterok z redakcji „Robotnika” dążył do pogodzenia marksizmu i chrześcijaństwa [P.P.S. Wspomnienia z lat 1918-1939 1987: 360, 524, 637, 727; Czerwoni chadecy z Cieszyna 1936]. O próbie nawiązania w 1926 r. dialogu z socjalistami przez ks. Jana Urbana SJ, redaktora naczelnego „Przeglądu Powszechnego" zob. [Jagiełło 1987].
} 
Obie formacje uważano za obce i wrogie katolikowi. „Walczymy z komunizmem, gdyż komunizm to wróg Boga i człowieka. Ale z nie mniejszą zajadłością winniśmy walczyć z kulturą, którą wiek XIX narzucił chrześcijaństwu. [...] Walkę widzimy na dwa fronty”. Szukano więc trzeciej drogi. „Dialektyka marksistowska nie przewiduje [...] trzeciego czynnika, gdy dwa są w walce, my zaś wierzymy, że ten trzeci czynnik jest możliwy, my chcemy go tworzyć". Tym trzecim czynnikiem, trzecią drogą miał być katolicyzm. ,Jesteśmy w chwili, w której świat czeka nowego wyrazu życia. Kościół mu niesie Ewangelię. Oparci o Niego chcemy tworzyć nowe bezkompromisowe oblicze świata. Niech wyraz »katolicki« przestanie być synonimem wyrazu »zacofany «". Cechą charakterystyczną PAKS była zarazem otwartość ideowa. „Wszystko co na świecie jest dobre, jest tym samym boskie, nasze, katolickie. Nie można więc z góry odrzucać żadnego środowiska, żadnego ruchu ideowego czy kulturalnego. Nie wolno od wyznawców obcej idei odgradzać się murem jak od trędowatych, zawsze i wszędzie, bo w ten sposób odbieramy Bogu coś, co jednak do niego należy", czytamy w artykule $O$ nadrzędnej roli katolicyzmu, opublikowanym przez „Pax” w 1937 r. [Kakareko 2000].

$\mathrm{Na}$ środowisko postępowo-katolickie spadły jednak nowe ciosy. W 1935 r. ks. Hlebowicz został wysłany na parafię w odległych Trokach, a ks. Meysztowicz do pracy w Watykanie. Rok akademicki 1934/1935 był ostatnim rokiem działalności PAKS. Kontynuowało wprawdzie jego myśl Towarzystwo „Pax” założone w $1935 \mathrm{r}$. [Gajewski 1987: 271], jednak wydawane przezeń pismo przejawiało, jak napisał bynajmniej nie na wyrost K. Turowski, ,pewne inklinacje nacjonalistyczne i totalistyczne" [Turowski 1987: 291].

\section{„PRAWDA I CZYN”}

Wyrazisty choć lokalny ośrodek katolickiego radykalizmu pojawił się również w Częstochowie. Radykalizacji uległ tamtejszy oddział Stowarzyszenia Młodzieży Chrześcijańsko-Społecznej (młodzieżówka prosanacyjnego Zjednoczenia Chrześcijańsko-Społecznego), głoszący swe poglądy w dwutygodniku „Prawda i Czyn” (Władysław Całus, Edward Galewicz, Hieronim Kubicki, Leopold J. Piątkowski) [Krzywobłocka 1974: 435]. Po zaprezentowaniu w numerach 8 i 9 z 1934 r. własnego programu pismo straciło źródła finansowania i przestało się ukazywać, jednak w 1937 r. grupa częstochowska podjęła próbę wznowienia go pod szyldem Związku Katolików Radykalnych [Do katolików czynu i wszystkich Polaków 1937; Od Wydawnictwa 1937]. Winieta tej „Jednodniówki katolicko-radykalnej” - motto (Mt 10:34) i charakterystyczny symbol krzyża o ściętych ukośnie końcach ramion - wykazywała podobieństwo z winietą krakowskiego „Zbawcy Ludu”.

Częstochowska grupa radykalnych katolików przedstawiała się jako bojownicy „Kościoła Wojującego” [Do katolików czynu i wszystkich Polaków 1937]. Podkreślała swą prawowierność, zapewniając, że stoi „na fundamencie dogmatów i prawideł 
moralności Rzymsko-Katolickiego Kościoła” i chce „zawsze pozostawać w zgodzie i jedności z hierarhią [!] duchowną" [My katolicy radykalni 1937]². Istotnym elementem programu „Prawdy i Czynu” były skrajnie konserwatywne postulaty obyczajowe: „cenzus moralny” na stanowiskach kierowniczych, wzmocnienie rodziny, ograniczenie pracy zarobkowej kobiet, zakaz pornografii czy nawet kabaretów [Program ogólny Zwiazku Katolików Radykalnych 1937]. Krytykowano koedukację (nawet na plaży czy boisku) i głoszono, że „Czystość obyczajów [jest] gwarancją mocarstwowości Polski" [Ogłaszamy ankietę 1934; Jakie artykuły gotowe do druku posiada Redakcja? 1934].

W publicystyce pisma można też jednak dostrzec pewne tendencje antyklerykalne. „Prawda i Czyn” deklarowała: „Nie będziemy się zanadto trzymać księżej sutanny, ani też [...] ustawicznie powoływać się na Pismo Święte i encykliki papieskie" [My katolicy radykalni 1937]. Pismo krytykowało bierność, chciwość i zeświecczenie duchowieństwa, rozpisało nawet ankietę dotyczącą sposobu uposażenia duchownych, aby skończyć z „wyzyskiem i handlem w kościele” [Reforma duszpasterstwa i Akcji Katolickiej 1937; Ogłaszamy ankietę Nr. [!] 1 1937]. Zapowiadano publikację w kolejnych numerach artykułów o wiele mówiących tytułach: „Opłaty za posługi religijne w świetle prawdy”, „Szanuję religię, nie wierzę księdzu”, ,Księża nie powinni mieć gospodyń”, „Odpust czy rozpust”, „Wikariusze budują, proboszczom gratulują" [Jakie artykuly gotowe do druku posiada Redakcja? 1937].

„Prawda i Czyn” podkreślała odmienność swego katolicyzmu, który miał być „katolicyzmem czynu” [Bądźmy katolikami czynu! 1934]. Pisała: „chcemy [...] bezczynności katolików ślamazarnych przeciwstawić czyn. [...] czynem chcemy wyznawać katolicyzm!" [Do katolików czynu i wszystkich Polaków 1937]. Od głównego nurtu polskiego katolicyzmu grupę częstochowską odróżniał jednak nie tylko dynamizm i aktywizm, ale też radykalizm społeczny. Wprost oznajmiano, że „,[d]otychczasowy $[\ldots]$ konserwatywny $[\ldots]$ lub burżuazyjny $[\ldots]$ katolicyzm musi się stać $[\ldots]$ postępowym, radykalnym i rewolucyjnym”, gdyż ,[j]eżeli katolicyzm chce panować nad masami [...] musi się [...] zradykalizować" [F.G. 1937]. Brak radykalizmu był wręcz przedstawiany jako grzech przed Bogiem za niedostrzeganie znaków czasu.

Radykalizm „Prawdy i Czynu” wyrażał się głównie w sferze społeczno-gospodarczej (kwestie polityczno-ustrojowe uważano za drugoplanowe, ograniczając się do ogólników, jak ,naród zorganizowany w [...] zdyscyplinowane państwo”) [My katolicy radykalni 1937]. Katolicy radykalni dystansowali się zarówno od marksistowskiego programu nacjonalizacji przemysłu i centralnego planowania, jak i od wolnorynkowego kapitalizmu. Krytykowali dogmaty liberalizmu ekonomicznego [Mentalność niedorozwoju 1937], potępiali „darmozjadów kapitalistycznych bez sumień, ojczyzny i Boga” [E.D. 1937], oburzali się, że „[g]łodni chłopi mają płacić

2 Co więcej, w 1934 r. „Prawda i Czyn” występowała przeciw równouprawnieniu wyznań, a nawet domagała się pełnych praw obywatelskich tylko dla praktykujących katolików [Polska państwem mocarstwowem i katolickiem 1934]. 
hulającym zagranicą arystokratom za ziemię, którą kiedyś dekretami szlacheckiej republiki ukradziono ludowi” [Obóz obludników! 1937].

Jako alternatywę proponowali projekt „trzeciej drogi” opartej na katolickiej nauce społecznej. Jego filarami miały być korporacjonizm, upowszechnienie własności i reforma monetarna [Prawda o socjalizmie i bolszewickim komunizmie 1934; Uwłaszczenie mas 1934; Proletarjatowi prawdziwa pomoc niosa katolicy 1934]. „Powszechne uwłaszczenie ludu pracującego” planowano przeprowadzić przez parcelację majątków ziemskich bez odszkodowania i obowiązkowe przekazanie pracownikom 1/3 akcji przedsiębiorstw. Życie gospodarcze regulowałyby korporacje jako instytucje prawa publicznego, ustawowo obdarzone uprawnieniami w zakresie kontroli produkcji, rozjemstwa, ochrony socjalnej, szkolnictwa zawodowego, prawa pracy, ustalania cen i norm jakościowych. Obowiązujący standard złota postulowano zastąpić pieniądzem opartym na masie towarowej. Dodatkowo żądano ustanowienia płacy rodzinnej (której wysokość byłaby zależna od liczby dzieci) i przymusu zatrudnienia bezrobotnych przez przedsiębiorstwa według wskazań korporacji [Katechizm społeczny Stow. Młodz. Chrześc.-Społ. 1937; Program ogólny Zwiazku Katolików Radykalnych 1937]. W rezultacie Związkowi Katolików Radykalnych zarzucano wręcz komunizowanie [Z tygodnia na tydzień 1937].

Taki program konfliktował ZKR z praktycznie wszystkimi siłami politycznymi. Hymn Związku Katolików Radykalnych wyliczał przeciwników: „Nie chcemy mądrości ze Wschodu, / Rabinów czy mongolskich hord [...] / Cielcowi złotemu Zachodu / śmiertelny zgotujem wnet cios [...] / Nie olśni nas blaga faszyzmu, / Liberał nie zwiedzie już nas" [Hymn Związu Katolików Radykalnych 1937]. Radykalni katolicy zachowywali dystans zarówno wobec sanacyjnego rządu (w stosunku do członków Legionu Młodych „Prawda i Czyn” domagała się nawet wykreślenia ich z ksiąg parafialnych!), jak i wobec wszystkich partii opozycyjnych z Chrześcijańską Demokracją włącznie. Symetrycznej krytyce poddawano „marksistowski bandytyzm” i „kłamstwo endeckie” [Poganie 1934; My katolicy radykalni 1937]. Lewicy zarzucano ateizm, szerzenie nienawiści klasowej i negację drobnej własności; pisano, że „gromadzi wokół siebie same zbrodnicze elementy [...] i męty społeczne oraz rozpustników i aferzystów spośród inteligencji” [Do walki z absurdem marksizmu 1937; por. Polsko, zbudź się! 1937]. Endeków oskarżano o wysługiwanie się klasom posiadającym i reakcyjny program społeczny; zapowiadano, iż „Pod endeckim [...] knutem tylko stękać będziemy mogli” [Obóz obłudników! 1937]. ZKR odżegnywał się też od antysemityzmu narodowców (,przeładowanie organizmu żydożerstwem”), uważając, że emigracja Żydów nie usunie kryzysu (nie zmienia to faktu, że „Prawda i Czyn" również postulowała unarodowienie gospodarki i zapowiadała ogłoszenie swojego „Programu walki z żydami” [Osobiste 1937; My katolicy radykalni 1937; Jakie artykuły gotowe do druku posiada Redakcja? 1937]. Odrzucając istniejące partie, radykalni katolicy postulowali stworzenie „Szarego Frontu” - ,jednolitego Frontu Katolickiego radykalnej przebudowy społeczno-gospodarczej” [My katolicy radykalni 1937]. 


\section{INDYWIDUALNOŚCI}

Myśl chrześcijańsko-radykalna to nie tylko grupy i środowiska, ale też pojedynczy intelektualiści. Bodaj najbardziej znanym przykładem jest Karol L. Koniński, publicysta wywodzący się z obozu narodowego. Już w 1928 r. w szkicu $Z$ tęsknot i myśli kryzysu krytykował kapitalizm, pisząc, że jest „wyrazem a-metafizycznego ducha czasu, obcy jest jakimkolwiek ideom ascezy. [...] Typowy kapitalista jest człowiekiem na wskroś niereligijnym". Choć zgodnie z katolicką nauką społeczną uważał, że własność osobista jest niezbędna dla zagwarantowania jednostce wolności i godności, to twierdził zarazem, że powinna być ona ograniczana w imię sprawiedliwości społecznej przez system podatkowy, udział pracowników w zyskach i zarządzaniu, a nawet wywłaszczenie i parcelację. Pragnął, „żeby znieść owo głębokie osamotnienie, owo nowożytne, atomistyczne rozproszenie społeczne" przez „radykalne przyspieszenie ewolucji społecznej w kierunku zmniejszenia wyzysku człowieka przez człowieka”. Prowadzić ku temu miała „myśl [...] »radykalnie ewolucyjna", [...] która zasadniczą i namiętną krytykę ustroju obecnego jednoczy ściśle z intencjami kulturalnie zachowawczymi”, wyrażana przez teoretyka „państwa stanowego" Othmara Spanna i „chrześcijańskiego socjalistę” Nikołaja Bierdiajewa [Koniński 2014: 162, 165, 168, 170, 179].

Podobne fascynacje były wówczas szeroko rozpowszechnione wśród „młodych" narodowców, Konińskiego odróżniał jednak od nich pozytywny stosunek do demokracji. Sceptycznie odnosił się do koncepcji ustroju hierarchicznego, potępiał totalitarny „uniwersalizm” społeczeństwa masowego, odbierający jednostce ,jej rzeczywistość, godność, inicjatywę i swobodę twórczą". Wbrew antyparlamentarnym tendencjom obozu narodowego postulował ,naprawę [...] parlamentaryzmu przez sam parlamentaryzm”. Głosił niezawisłość sądów. Domagał się „państwa prawnego", w którym ,istnieje [...] dookoła człowieka prawem zawarowany krąg jego swobody, bezpieczeństwa, godności”, „nietykalne a ściśle określone residuum praw i swobód” obywatelskich. Bronił wolności myśli i słowa - „nawet tych, które przeciwne są założeniom i ideom naczelnym danej kultury" [Koniński 2014: 176-178, 197, 370, 468, 507].

Ideologią Konińskiego był - jak określiła s. Teresa w „Verbum”- „,bezfanatyczny teologicznie, ale moralnie nieustępliwy chrześcijański humanizm” [Teresa 1938]. Stawiało go to na antypodach faszyzmu. Koniński potępiał totalitaryzm, imperializm i rasizm ideologii nazistowskiej, pisał, że „hitlerostwo [...] godzi w najgłębsze podstawy kultury chrześcijańskiej i humanitarnej”. Podzielający dotąd endecką niechęć wobec Żydów pisarz zrewidował swój antysemityzm - choć zapewniał, że „do filosemitów nie przystanę", to potępiał amoralny „hotentotyzm” antysemitów, a nawet dostrzegał zbieżność interesu polskiego i żydowskiego wobec Niemiec hitlerowskich. Nawet zagrożenie bolszewickie uważał za mniejsze od hitlerowskiego. Twierdził, że wojna przeciw nazizmowi (choćby w sojuszu z ZSRR) „uzyska sens religijny”, gdyż nadszedł „czas definitywnego wyboru między chrześcijańską a swastycką ideą”. 
$\mathrm{Z}$ tego powodu głębokim niesmakiem napawały go przypadki motywowanego Realpolitik kompromisu hierarchii kościelnej (np. w Austrii po Anschlussie) z III Rzeszą [Koniński 2014: 321, 324, 333, 438-439, 496-500, 550, 578].

Zbliżony charakter miały rozważania zapomnianego ideologa „katolickiego socjalizmu", nauczyciela z Kościana, doktora filozofii Adama Mikiewicza. Mikiewicz przyłączył się do krytyki kapitalizmu, uważając, że rodzi on „niemoralną zależność pracy od kapitału i nędzę gospodarczą rzesz pracujących”. Co więcej, dostrzegał destrukcyjne skutki liberalizmu dla moralności, pisząc, że „osłabił lub rozbił życie rodzinne i społeczne”. Przyczyna tego miała leżeć w brutalności wolnej konkurencji, która (tu przywoływał "Quadragesimo Anno”) „,daje zwycięstwo tylko najsilniejszym, t.j. tym, którzy walczą najbezwzględniej i którzy nie znają skrupułów sumienia”. Mikiewicz powtarzał więc za kardynałem Augustem Hlondem: „Ustrój społeczny wymaga bezwzględnej naprawy [...] [gdyż] na arenie społecznej figuruje już jako stałe zjawisko proletariat żyjący w niezasłużonej beznadziejnej nędzy, i [...] w podziale własności zachodzą różnice rażące i nieuzasadnione" [Mikiewicz 1939: $10,12,15,18]$.

Z drugiej strony kwestionował socjalistyczną antytezę kapitalizmu, która również rozrywa organiczną jedność społeczeństw, a w dodatku ma charakter utopijny, ponieważ nie uwzględnia naturalnej interesowności człowieka. Przede wszystkim jednak opozycja katolicyzmu i socjalizmu wynikała z różnic światopoglądowych (,podbudowy transcendentnej”). To prowadziło Mikiewicza do wniosku, że „nie może być mowy o kompromisie z [materialistycznym - J.T.] socjalizmem, ponieważ podstawy jego są niechrześcijańskie". Widział jednak możliwość przezwyciężenia tego antagonizmu w duchu ,dynamicznego tomizmu” kardynała Johna Newmana. Mikiewicz stwierdzał, że katolicyzm i socjalizm operują na różnych płaszczyznach: katolicyzm kładzie nacisk na etykę, socjalizm - na „technikę” (tj. organizację społeczną). Zwracał więc uwagę na zbieżności obu systemów ideowych: „energizm i kooperatywizm oraz ewolucyjność”. Pisał, że chrześcijaństwo „nadaje każdej jednostce, niezależnie o jej stanowiska społecznego - godność i dostojeństwo", podnosi pracę człowieka do „najwyższej godności”, głosi ,ideał dobrobytu społecznego Królestwo Boże - warunkiem do niego jest [...] praca uspołeczniona t.j. czynna miłość bliźniego" [Mikiewicz 1939: 5, 7-8, 10, 13, 15].

Wiązał się z tym program konkretnych reform społecznych. Ustrój społeczny, pisał Mikiewicz, powinien być „na usługach ogółu społeczeństwa, które pracuje” i zapewniać „sprawiedliwy podział dóbr, z tym warunkiem, aby nie ucierpiała produkcja”. Osiągnąć ten cel można było przez „socjację”, czyli ,gospodarcze zrzeszenie pracy”: korporacje, współwłasność pracowniczą, spółdzielczość, „banki wymiany pracy”. „Stałym czynnikiem, który będzie regulował rozumnie (sprawiedliwie) mechanizm popytu i podaży będzie zrzeszona i świadoma praca", pisał Mikiewicz. Samoorganizację społeczeństwa winno wspierać państwo, ale przy zastrzeżeniu zasady subsydiarności. Drugim filarem nowego ustroju miało być upowszechnienie własności (uwłaszczenie proletariatu), gdyż „pełną odpowiedzialność i inicjatywę 
okazują indywidualne warsztaty pracy". Obywatelskie izby gospodarcze miały kontrolować obieg gospodarczy. Całości dopełniałby progresywny system podatkowy i rozbudowana opieka socjalna [Mikiewicz 1939: 18-22, 24-25].

\section{ZAKOŃCZENIE}

Przegląd inicjatyw chrześcijańsko-radykalnych można podsumować generalizującą charakterystyką i oceną nurtu. Nie możemy mówić o jednolitej formacji ani nawet ruchu, gdyż mamy do czynienia ze zjawiskiem policentrycznym - archipelagiem grup i jednostek podzielających podobne wartości, ale tworzących i działających niezależnie od siebie. W olbrzymiej większości byli to przedstawiciele akademików i młodej inteligencji, z rzadka uzupełniani przez pojedynczych duchownych; określić moglibyśmy ich mianem outsiderów. Ich inspiracją był na ogół niszowy, choć modny radykalny katolicyzm francuski (nie sposób odnaleźć w twórczości polskich postępowych katolików odwołań do ks. Piotra Ściegiennego czy Leona hr. Rzewuskiego) [Sikorski 2018: 43-150, 437-484]. Radykalizm nurtu postępowo-chrześcijańskiego z zasady starał się nie wykraczać poza pryncypia katolickiej nauki społecznej, odróżniał się innym rozłożeniem akcentów - większy nacisk kładł na demokrację, antykapitalizm, a zwłaszcza antyfaszyzm. Poza indywidualnymi wyjątkami przedstawiciele tego nurtu nie decydowali się na przekraczanie ideowego Rubikonu, by zadeklarować się jako ludzie „lewicy” czy zwolennicy „socjalizmu”. Nie przybrali nawet wyróżniającej ich wspólnej nazwy.

Choć olbrzymia większość polskich chłopów i niewiele mniejsza robotników była katolikami, idee chrześcijańskich radykałów nie znajdowały w masach żadnego oddźwięku. Wynikało to z kilku przyczyn. Po pierwsze, importowane z Francji przez młodych inteligentów koncepcje były nazbyt oderwane od życia prostych ludzi. Analizowana publicystyka pism postępowo-katolickich miała hermetyczny charakter, była adresowana do wąskiego kręgu intelektualistów. Po drugie, w polskiej rzeczywistości lat 30., charakteryzującej się brutalną walką między sanacją a endecką i centrolewicową opozycją, nie było miejsca na synkretyczne inicjatywy ${ }^{3}$. Przypadek środowiska wileńskiego, które rozdarła ideowopolityczna polaryzacja, jest wystarczająco dobitny. Po trzecie wreszcie, Kościół instytucjonalny w zarodku gasił wszelkie nazbyt radykalne działania (czego przykładem były losy Dembińskiego).

Chrześcijański radykalizm nie odniósł sukcesu. Niemniej jednak Ryszard Hermanowicz i Czesław Strzeszewski twierdzą, że „w ostatnim okresie przed drugą wojną światową [...] chrześcijański ruch robotniczy wkraczał w fazę rokującą wielki rozwój. Zaznaczało się to w większej aktywności członków, odmłodzeniu kadry,

\footnotetext{
3 Zwłaszcza młoda endecja skutecznie acz demagogicznie łączyła hasła katolickie i socjalradykalne. Z kolei marksistowska i liberalna opozycja była nastawiona antyklerykalnie, od sanacji zaś postępowych katolików odróżniał stosunek do demokracji.
} 
zwłaszcza kierowniczej, którą zasilały organizacje Akcji Katolickiej, przede wszystkim młodzieżowe" [Historia katolicyzmu społecznego w Polsce 1981: 508]. Biorąc pod uwagę sukcesy europejskiej (np. francuskiej) chadecji po II wojnie światowej, nie można wykluczyć, że w innym układzie geopolitycznym radykalny ruch katolicko-społeczny mógłby sięgnąć po hegemonię w Polsce.

\section{BIBLIOGRAFIA}

Blüth, R.M. 1936. Kominternowe flirty z katolikami, „Verbum”, z. 4.

Braun, F.M. 1937. Co wspótczesność przeciwstawia Ewangelii, „Verbum”, z. 4.

Caro, L. 1935. Ekonomika przyszłości, „Verbum”, nr 1.

Chrzanowski, W.J. 1999. „Verbum”- w stużbie katolicyzmu dynamicznego, „Inspiracje”, nr 6.

Czerwoni chadecy z Cieszyna, „Polska Zachodnia” 1936, nr 193.

Do katolików czynu i wszystkich Polaków, szukajacych prawdy!, „Prawda i Czyn” (Jednodniówka) 1937.

Do walki z absurdem marksizmu, „Prawda i Czyn” (Jednodniówka) 1937.

Dwie wolności, 1937, „Verbum”, z. 4.

E.D., Z pod dyktatury złotego Molocha, „Prawda i Czyn” (Jednodniówka) 1937.

F.G., Potrzeba radykalizmu katolickiego, „Prawda i Czyn” (Jednodniówka) 1937.

Gajewski, S. 1987. Katolickie organizacje akademickie w II Rzeczypospolitej [w:] Z dziejów katolicyzmu społecznego, R. Bender, J. Kondziela, S. Gajewski (red.), RW KUL, Lublin.

Hellman, J. 2002. The Communitarian Third Way. Alexander Marc and Ordre Nouveau, 1930-2000, McGill-Queen's University Press, Montreal-London.

Hymn Zwiazzu Katolików Radykalnych i Stowarzyszenia Młodzieży Chrześcijańsko-Społecznej, „Prawda i Czyn" (Jednodniówka) 1937.

Jagiełło, M. 1987. Próba rozmowy, „Przegląd Powszechny”, nr 7-8.

Jakie artykuły gotowe do druku posiada Redakcja?, „Prawda i Czyn” (Jednodniówka) 1937.

Jolivet, R. 1935. Argument sceptyków oparty na błędach rodzaju ludzkiego, „Verbum”, nr 1.

Kakareko, A. 2000. Od „Kaziuka” do Maritain 'a, czyli o mlodej inteligencji wileńskiej lat trzydziestych i jej stosunku do różnic i odrębności narodowościowych na przykładzie środowisk seniorów „, Akademickiego Klubu Włóczęgów” oraz „Porozumienia Akademickich Katolickich Stowarzyszeń” (,,PAKS”), [w:] Polacy i sasiedzi - dystanse i przenikanie kultur, cz. I, R. Wapiński (red.), Wydawnictwo Stepan design, Ostaszewo Gdańskie.

Katechizm spoteczny Stow. Młodz. Chrześc.-Spot., „Prawda i Czyn” (Jednodniówka) 1937.

Koniński, K.L. 2014. Pisma polityczne, Wydawnictwo Arcana, Kraków.

Krzywobłocka, B. 1974. Chadecja 1918-1937, Książka i Wiedza, Warszawa.

Lewis, D.L. 1970. Emmanuel Mounier and the Politics of Moral Revolution: Aspects of Political Crises in French Liberal Catholicism, 1935-1938, "Catholic Historical Review", nr 2.

List Episkopatu Niemieckiego, 1934, „Verbum”, z. 3.

Łętocha, R. 2008. Władysław Korniłowicz - Ksiadz, stup w sutannie żywego ognia, „Obywatel”, nr 5.

Maritain, J. 1934. Filozofia przyrody, „Verbum”, z. 3.

Mentalność niedorozwoju, „Prawda i Czyn” (Jednodniówka) 1937.

Mikiewicz, A. 1939. Katolicki-socjalizm, bmw.

Morawska, H. 1936. Erazm z Rotterdamu, „Verbum” 1936, z. 4.

My katolicy radykalni, „Prawda i Czyn” (Jednodniówka) 1937.

Myczka, E. bdw. O polska ideę czynu, Poznań.

Niesiołowski, A. 1938. Personalizm i jego perspektywy, „Verbum”, z. 3.

Obóz obludników!, „Prawda i Czyn” (Jednodniówka) 1937. 
Od Wydawnictwa, „Prawda i Czyn” (Jednodniówka) 1937.

Ogłaszamy ankiete, ,Prawda i Czyn” 1934, nr 1.

Ogłaszamy ankietę Nr. [!] 1, „Prawda i Czyn” (Jednodniówka) 1937.

Osobiste, „Prawda i Czyn” (Jednodniówka) 1937.

Poganie, „Prawda i Czyn” 1934, nr 4.

Polska państwem mocarstwowem i katolickiem, „Prawda i Czyn” 1934, nr 1.

Polsko, zbudź się!, „Prawda i Czyn” (Jednodniówka) 1937.

P.P.S. Wspomnienia z lat 1918-1939, 1987, Warszawa.

Prawda o socjalizmie i bolszewickim komunizmie, „Prawda i Czyn” 1934, nr 1.

Program Chtopskiego Stronnictwa Radykalnego, 1922, Warszawa.

Program ogólny Związu Katolików Radykalnych, „Prawda i Czyn” (Jednodniówka) 1937.

Program Narodowego Zwiazku Chrześsijańsko-Społecznego, 1919, Kraków.

Proletarjatowi prawdziwa pomoc niosa katolicy, „Prawda i Czyn” 1934, nr 5.

Reforma duszpasterstwa i Akcji Katolickiej, „Prawda i Czyn” (Jednodniówka) 1937.

Rek, T. 1962. Ksiądz Eugeniusz Okoń 1881-1949, Ludowa Spółdzielnia Wydawnicza, Warszawa.

Sałamucha, J. 1936. Z za kulis filozofii chrześcijańskiej, „Verbum”, z. 4.

Sikorski, T. 2018. Ewangelia Zbawienia. Polska lewica chrześcijańska (1832-1914), Wydawnictwo Znak, Warszawa-Radzymin.

Siwecki, J. 1934. W obronie humanizmu, „Verbum”, z. 3.

Siwecki, J. 1938. O postawę katolików wobec komunizmu, „Verbum”, z. 3.

Spiss, T. 1936. Ze wspomnień c. k. urzędnika politycznego, Rzeszów.

Strzeszewski, Cz., Bender, R., Turowski, K. (red.). 1981. Historia katolicyzmu społecznego w Polsce 1832-1939, Ośrodek Dokumentacji Studiów Społecznych, Warszawa.

Teresa, 1935. Mistyka a katolicyzm, „Verbum”, nr 1.

Teresa. 1938. O chrześcijańska odbudowe świata, „Verbum”, z. 3.

Tomasiewicz, J. 2007. We wszystkim - Miłość, „Obywatel”, nr 5.

Tomasiewicz, J. 2018. „Walkę toczyć musimy na trzy fronty...” Robotniczy radykalizm chrześcijański w II Rzeczypospolitej na przykladzie ,ZZbawcy Ludu”, [w:] Politologia religii, M. Marczewska-Rytko, D. Maj (red.), Wydawnictwo UMCS, Lublin.

Turowski, K. 1987. „Odrodzenie”. Historia Stowarzyszenia Katolickiej Młodzieży Akademickiej, Ośrodek Dokumentacji i Studiów Społecznych, Warszawa.

Uwtaszczenie mas, „Prawda i Czyn” 1934, nr 2.

Walka z radykalizmem mlodych, „Sprawy Polityczne” 1934, nr 362.

Włudyka, T. 1994. „Trzecia droga” w myśli gospodarczej II Rzeczypospolitej: koncepcje Adama Doboszyńskiego a program obozu narodowego, Universitas, Kraków.

Wyka, K. 1935. Prądy duchowe wśród młodzieży francuskiej, „Marchołt”, $\mathrm{nr} 4$.

Z tygodnia na tydzień, „Goniec Częstochowski” 1937, nr 234.

Zarys programu Chrześcijańsko-Narodowego Stronnictwa Pracy (Chrześcijańskiej Demokracji), 1922,Warszawa.

\section{THE “FOURTH WAY”. THE CHRISTIAN RADICALISM IN THE SECOND REPUBLIC}

Abstract: The subject of this article is the ideology of Christian radicalism in interwar Poland. The method applied is text analysis in the sociopolitical context. The essence of the Christian radicalism was the synthesis of social reforms program and defense of democracy on the basis of Catholicism. The author aims to answer the question: What was the reason for the weakening of this tendency. The main cause was the elite character of the Christian-radical movement embodied by some academic associations (e.g. "Odrodzenie") and intellectual magazines (e.g. "Verbum").

Keywords: Second Republic, social Catholicism 


\section{BIOGRAM}

Jarosław Tomasiewicz, dr hab. prof. UŚ na Wydziale Humanistycznym Uniwersytetu Śląskiego. Badacz idei i ruchów radykalnych. Autor m.in. Rewolucja Narodowa. Nacjonalistyczne koncepcje rewolucji społecznej w Drugiej Rzeczypospolitej (2012); Naprawa czy zniszczenie demokracji? Tendencje autorytarne i profaszystowskie w polskiej myśli politycznej (1921-1935) (2012); Po dwakroć niepokorni. Szkice z dziejów polskiej lewicy patriotycznej (2014); W kierunku nacjokracji. Tendencje autorytarne, totalistyczne i profaszystowskie w polskiej myśli politycznej (1933-1939): narodowcy - narodowi radykatowie - narodowi socjaliści (2019). Kontakt e-mail: jaroslaw.tomasiewicz@us.edu.pl. 